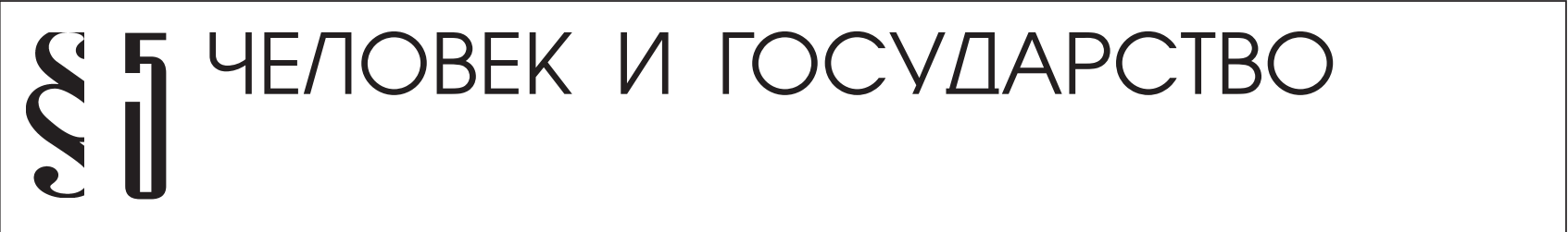

Конохов М.В.

\section{ИНСТИТУТ ОБЯЗАТЕЛЬНОГО ГОСУДАРСТВЕННОГО СТРАХОВАНИЯ ЖИЗНИ И ЗДОРОВЬЯ ВОЕННОСЛУЖАЩИХ В КОНСТИТУЦИОННО-ПРАВОВОМ ПРОСТРАНСТВЕ РОССИЙСКОЙ ФЕДЕРАЦИИ}

\begin{abstract}
Аннотация: В статье рассматривается место института обязательного государственного страхования в системе военного права, рассматриваются особенности реализации указанного правового института и проблемы осуществления военнослужащими права на обязательное государственное страхование жизни и здоровья, делается вывод о том, что институт обязательного государственного страхования жизни и здоровья военнослужащих является комплексным правовым институтом, и относится именно к институту военного права, а также что данный институт выводит Российское государства в разряд передового, соииального ориентированного гражданского общества, где права и свободы человека обеспечиваются в должных параметрах органов правосудия.

Abstract: The article considers the place of compulsory state insurance institution in the system of military law, discusses the features of implementation of this legal institution and the challenges faced by the military personnel during the implementation of the right to compulsory state life and health insurance; it is concluded that the institution of compulsory state insurance of life and health of the military personnel is a complex legal institution; it is specifically related to the institution of military law and places the Russian Federation among the technologically advanced, socially-oriented civil societies where human rights and freedoms are provided within the proper parameters of justice. Ключевые слова: Юриспруденция, личное страхование, комплексный институт, военное право, военнослужащие, международные обязательства, конституционное право, права человека, частные начала, публичные начала Keywords: Jurisprudence, private insurance, comprehensive institution, military law, military personnel, international obligations, constitutional law, human rights, private principles, public principles.
\end{abstract}

П озиционирование Российской Федерации в современном миропорядке как правового, демократического, социального государства, предметно заявившего о своей приверженность верховенству права (Декларации тысячелетия 2000 г., Итоговый документ Всемирного саммита 2005 г.), определяется добросовестным выполнением международных обязательств независимо от источника их возникновения. Прежде всего, речь идёт об обязательствах согласно Уставу ООН (п. 2 ст.2) и далее уже по всей источниковой базе современного международного права (ст. 38 Статута Международного суда).

Важное место в международных договорно-правовых отношениях Российской Федерации занимает международное сотрудничество по линии выполнения постановлений Устава в части поощрения и развития уважения к правам человека и основным свободам для всех, без различия расы, пола, языка и религии (п. 3 ст.1 Устава ООН). Базовое, нормоустонавливающее значение (в плане своей обязательности для контрагентов) составляют собой Международный пакт о гражданских и политических правах и Международный пакт об экономических, социальных и культурных правах от 16 декабря 1966 г. Созданные в развитие обозначенных договорно-правовых актов институционные механизмы контроля - Комитет по правам человека и Комитет по экономическим, социальным и культурным правам - обозначают себя в качестве действенных способов по линии выполняемости постановлений международных пактов.

Российская Федерация как добросовестный участник современных международных правоотношений 
DOI: 10.7256/1811-9018.2014.2.7241

При цитировании этой статьи сноска на doi обязательна

\section{Право и политика 2 (170) 2014}

через институт имплементации ${ }^{1}$ норм международного права в правовой системе России осуществляет весь комплекс надлежащих мер на законодательном, исполнительном и судебном уровнях по всестороннему соблюдению положений Международных пактов 1966 г.

Позитив конституционно-правового строительства Российской Федерации, как он определяет себя в параметрах принципа приоритета применяется применения правила международных договоров (п. 4 ст. 15 Конституции России), принципа обеспечения прав человека через международные судебные институты (ст.46 Конституции России), принципа прямого действия Конституции России в аспекте установления её высшей юридической силы на всей территории Российской Федерации (ст. 15 Конституции России), предметно и целенаправленно сказывает своё позитивное воздействие на весь процесс по имплементации предписаний Международных пактов о правах человека 1966 г. в правовой системе Российской Федерации. В рамках предметной регулятивной направленности каждый из пактов осуществляет своё положительное воздействие на всю систему гражданских, политических, экономических, социальных, культурных правоотношений в пространственных пределах Российской Федерации.

Институт обязательного государственного страхования жизни и здоровья военнослужащих по обстоятельствам своего юридического существа входит в сферу правового воздействия постановлений ст. 7 и 8 Конституции Российской Федерации, согласно которым Россия провозглашается социальным государством, и правового режима Международного пакта об экономических, социальных и культурных правах 1966 г. Через призму принятых международных обязательства (согласно пакту) Российская Федерация в общих параметрах первой главы Конституции России «Основа Конституционного права» проводит действенную социальную политику, обеспечивающую достойную жизнь и свободное развитие человека (ч.1 ст. 7). Тем самым, вполне обоснованным звучит концептуальное заключение авторитетных российских учённых о значимости статуса социальной политики государства в общих параметрах конституционно-правового поля

\footnotetext{
${ }^{1}$ См. Черниченко С.В. Теория международного права. Т. 1. М., 1995.c. 140-160; Зимненко Б.Л. Международное право и правовая система Российской Федерации. М., 2006. С.63; Гавердовский А.С. Имплементация норм международного права. Киев, 1980. С. 60-75; Каламкарян Р.А. Имплементация норм международного права в правовой системе РФ 1 Гражданин и права. 2011.№10 .c.3-13.
}

Российской Федерации ${ }^{2}$. Проявляющая себя в режиме конкретных юридических гарантий социальная политика Российской Федерации создаёт надлежащие правовые условия для действенного функционирования института обязательного государственного страхования жизни и здоровья военнослужащих на всём пространственном протяжении страны. Позитив правоприменительной практики Российского государства по линии обеспечения личных и имущественных прав военнослужащих Вооруженных Сил России показывает себя в должных параметрах правового, демократического, социального государства.

Между тем вопрос о месте института обязательного страхования в современной системе права носит дискуссионный характер. Главным отличительным признаком всех разновидностей обязательного государственного страхования является осуществление его в силу закона, в связи с чем в настоящее время ведется широкая научная дискуссия по вопросу месте института обязательного государственного страхования жизни и здоровья военнослужащих в современной системе права. Мнения ученых по данному вопросу разделяются на две категории. Одни ученые относят институт обязательного государственного страхования к сугубо гражданско-правовому институту, другие-к институту права социального обеспечения, имеющему в большей степени административно-правовой характер.

Для разрешения указанного дискуссионного вопроса, по мнению автора, прежде всего, необходимо определить в каких нормативных правовых актах содержатся нормы права, регулирующие осуществление обязательного государственного страхования жизни и здоровья военнослужащих. Эти нормы закреплены в гл. 48 Гражданского кодекса Российской Федерации от 26.11.2001 г. № 146-Ф3³, Законе Российской Федерации от 27 ноября 1992 г. № 4015-I «Об организации страхового дела в Российской Федерации» ${ }^{4}$ Условия и порядок осуществления обязательного государственного страхования жизни и здоровья военнослужащих определены Федеральным законом «Об обязательном государственном страховании жизни и здоровья военнослужащих, граждан, призванных на военные сборы, лиц рядового и начальствующего состава органов внутренних дел Российской Федерации, Государственной

\footnotetext{
${ }^{2}$ См.: Конституционное право России: учебник для студентов вузов / А.С. Прудников и др.; под ред. Б.С. Эбзеев, А.С. Прудников, В.И. Авсеенко. М., 2010. С. 86.

${ }^{3}$ См.: Собрание законодательства Российской Федерации. - 2001. - № 49, ст. 4552.

${ }^{4}$ См.: Рос. газ. 1993.12 января.
} 
противопожарной службы, органов по контролю за оборотом наркотических средств и психотропных веществ, сотрудников учреждений и органов уголовно-исполнительной системы и сотрудников федеральных органов налоговой полиции» от 28 марта 1998 г. № 52-Ф35 , Постановлением Правительства Российской Федерации «О мерах по реализации Федерального закона «Об обязательном государственном страховании жизни и здоровья военнослужащих, граждан, призванных на военные сборы, лиц рядового и начальствующего состава органов внутренних дел Российской Федерации, Государственной противопожарной службы, органов по контролю за оборотом наркотических средств и психотропных веществ, сотрудников учреждений и органов уголовно-исполнительной системы» от 29 июля 1998 г. № $855^{6}$.

Как видно из анализа нормативных правовых актов, в которых закреплен институт обязательного государственного страхования жизни и здоровья военнослужащих, а также порядок его реализации, они носят весьма неоднородный характер. Эти нормы закреплены в различных отраслях права. Это обстоятельство позволяет говорить о комплексном характере правового института обязательного государственного страхования жизни и здоровья военнослужащих.

Проанализируем нормативные правовые акты в области осуществления обязательного государственного страхования жизни и здоровья военнослужащих. Вышеназванным Законом Российской Федерации «Об организации страхового дела в Российской Федерации» от 27 ноября 1992 г. № 4015-I в качестве объекта личного страхования граждан установлены имущественные интересы, связанные с причинением вреда жизни и здоровью7. Данный закон отражает экономический характер страхования, так как целью личного страхования в соответствии с ним является именно имущественный интерес. Таким образом, установление данным законом в качестве объекта личного страхования имущественного интереса является весомым аргументом в пользу отнесения данного правового института к гражданско-правовым.

Сторонники отнесения обязательного государственного страхования к числу институтов права социального обеспечения в обоснование своего утверждения ссылаются на п. 1 ст. 969 Гражданского Кодекса Российской Федерации, в котором указано, что обяза-

\footnotetext{
${ }^{5}$ См: Рос. газ. 1998. 7 апреля.

${ }^{6}$ См.: Собр. законодательства Рос. Федерации. 1998. № 32. Ст. 3900.

${ }^{7}$ Рос. газ. 1993. 12 января.
}

тельное государственное страхование осуществляется в целях обеспечения социальных интересов граждан и интересов государства.

Кроме того, п. 4 ст. 969 Гражданского Кодекса Российской Федерации устанавливает приоритет специальных нормативных правовых актов в области обязательного государственного страхования жизни и здоровья военнослужащих над правилами, установленными главой 48 Гражданского Кодекса Российской Федерации. Это обстоятельство также подтверждает социальную направленность данного правового института.

В пользу социальной природы обязательного государственного страхования жизни и здоровья военнослужащих свидетельствует п. 1 ст. 18 Федерального закона «О статусе военнослужащих» от 27.05.1998 № 76-Ф38, в соответствии с которым финансирование расходов по обязательному государственному личному страхованию военнослужащих возлагается на федеральный бюджет. Указанная норма права содержится также и в иных нормативных правовых актах в названной области общественных отношений.

Особенность данного правового института отражена также в определении Конституционного Суда Российской Федерации № 17-П от 26 декабря 2002 г. по делу о проверке конституционности положения абзаца второго п. 4 ст. 11 Федерального Закона «Об обязательном государственном страховании жизни и здоровья военнослужащих, граждан, призванных на военные сборы, лиц рядового и начальствующего состава органов внутренних дел Российской Федерации, Государственной противопожарной службы, органов по контролю за оборотом наркотических средств и психотропных веществ, сотрудников учреждений и органов уголовно-исполнительной системы и сотрудников федеральных органов налоговой полиции» от 28 марта 1998 г. № 52-Ф3, где указано, что «обязательное государственное страхование военнослужащих и приравненных к ним лиц установлено в целях защиты их социальных интересов и интересов государства (п. 1 ст. 969 ГК РФ), является одной из форм исполнения государством обязанности возместить ущерб, который может быть причинен жизни или здоровью этих лиц при прохождении военной службы, следовательно в конституционно-правовом смысле страховое обеспечение, полагающееся военнослужащим и приравненным к ним лицам в соответствии с рассматриваемым Федеральным Законом,- наряду с иными

\footnotetext{
${ }^{8}$ Собр. законодательства Рос. Федерации. 1998, № 22. Ст. 2331.
} 
DOI: $10.7256 / 1811-9018.2014 .2 .7241$

При цитировании этой статьи сноска на doi обязательна

\section{Право и политика 2 (170) $\bullet 2014$}

выплатами, которые в целях возмещения вреда могут быть установлены им на основании других Законов, - входят в гарантированный государством объем возмещения вреда, призванного компенсировать объем возмещения их материального и социального статуса вследствие наступления страховых случаев, включая причиненный материальный и моральный вред. Таким образом, посредством обязательного государственного страхования жизни и здоровья, предполагающего выплату при наступлении страховых случаев соответствующих страховых сумм, военнослужащим и приравненным к ним лицам, обеспечивается право на возмещение вреда, причиненного жизни или здоровью, право на охрану здоровья защита имущественных прав, а также осуществляется гарантированное ст. 39 Конституции Российской Федерации социальное обеспечение граждан в случае болезни, инвалидности, потери кормильца и в иных случаях, установленных Законом»9. Из указанной правовой позиции Конституционного Суда Российской Федерации следует, что указанный судебный орган придерживается позиции социальной направленности рассматриваемого института права, при этом не исключая наличие гражданско-правовых начал в указанном правовом институте.

О социальной направленности института обязательного государственного страхования говорится и рядом ученых. Например, М.А. Ковалевский отмечает, что обязательное государственное страхование является одной из форм реализации конституционного института социального обеспечения ${ }^{10}$.

Сторонники иной позиции относят институт обязательного государственного страхования к числу сугубо гражданско-правовых институтов. А.Н. Мачкасов отмечает, что «обеспечение социальных интересов граждан является основной целью обязательного государственного страхования жизни и здоровья военнослужащих. Однако данный интерес является, прежде всего, имущественным, и застрахованные лица при наступлении страхового случая приобретают, прежде всего, право на получение страхового возмещения, которое выражается в денежном эквиваленте» ${ }^{11}$. Автор

\footnotetext{
9 Вестник Конституционного Суда Российской Федерации. 2003, № 1. C. $22-23$.

${ }^{10}$ Ковалевский М.A. Конституционные принципы в обязательном страховании военнослужащих и проблема ответственности страховщика. // Страховое право. 2002. № 4. С. 54.

${ }^{11}$ Мачкасов А.И. Осуществление обязательного государственного страхования жизни и здоровья сотрудников УИС. Дисс... канд. юрид. наук. Рязань, 2010. С. 53.
}

далее приходит к выводу о том, что обязательное государственное страхование к видам социального обеспечения не относится и элементом социального обеспечения его назвать нельзя ${ }^{12}$. Названный автор далее отмечает, что «...поскольку обязательное государственное страхование не является ни элементом государственной системы социального обеспечения, ни разновидностью социального обеспечения, то без всякого сомнения этот вид страхования следует признать категорией гражданско-правовой направленности» ${ }^{13}$.

Указанной позиции придерживается и Д.В. Савкин, который отмечает, что «страховое правоотношение между страхователем, страховщиком и выгодоприобретателем является гражданским правоотношением и подчиняется гражданскому законодательству» ${ }^{14}$. Исходя из рассуждений названного автора страховое правоотношение и гражданское правоотношение соотносятся между собой как общее и частное. Соответственно институт обязательного государственного страхования жизни и здоровья военнослужащих будет всегда относится к числу гражданскоправовых институтов. Здесь следует отметить, что названный автор при аргументировании своих выводов не учитывает мнения перечисленных выше ученых, которые отмечают социальную направленность института обязательного государственного страхования жизни и здоровья военнослужащих.

Разрешение противоречия между приведенными выше позициями может, по мнению автора, содержаться в исследовании стадий реализации указанного правового института.

Общепризнанным в юридической науке является мнение о наличии в современной системе права, устоявшегося правового института обязательного государственного страхования жизни и здоровья военнослужащих ${ }^{15}$. В этот правовой институт входят нормы права, регулирующие осуществление обязательного государственного страхования жизни и здоровья военнослужащих.

\footnotetext{
${ }^{12}$ Мачкасов А.И. указ. соч. С. 53.

${ }^{13}$ Мачкасов А.И. указ. соч. С. 53.

${ }^{14}$ Савкин Д.В. Страховое правоотношение по российскому гражданскому праву. Дис... канд. юрид. наук. М., 2003. С. 6.

15 Под правовым институтом мы понимаем систему взаимосвязанных правовых норм, являющихся специфической частью отрасли права и регулирующих относительно самостоятельную разновидность общественных отношений или какие либо их компоненты, свойства. См.: Энциклопедический словарь экономики и права URL: dic.academic.ru> дата обращения: 31.10.2012 права (электронный ресурс). Дата обращения: 31.10.2012.
} 
Автор статьи полагает, что особенности института обязательного государственного страхования жизни и здоровья военнослужащих заключаются в особенностях реализации норм права, в него входящих. Под реализацией норм права в данной статье мы будем понимать процесс фактического осуществления (претворения) в жизнь предписаний юридических норм в правомерном поведении граждан, должностных лиц и иных субъектов права ${ }^{16}$. Соответственно, в дальнейшем в настоящей статье мы будем говорить о реализации правового института обязательного государственного страхования жизни и здоровья военнослужащих, имея ввиду при этом реализацию норм права, в него входящих. Автор полагает, что процесс реализации института обязательного государственного страхования жизни и здоровья военнослужащих можно представить как совокупность определенных стадий, последовательно сменяющих друг друга ${ }^{17}$.

Нормы права реализуются в конкретных правоотношениях. Соответственно и институт обязательного государственного страхования жизни и здоровья военнослужащих также реализуется в конкретных правоотношениях по осуществлению обязательного государственного страхования жизни и здоровья военнослужащих. Как справедливо отмечает Л.А. Чеговадзе «гражданское правоотношение, как и всякая любая общественная связь, не является одномоментным явлением и протекает во времени более или менее длительный период» ${ }^{18}$. Этот вывод представляется верным также и для правоотношений в области осуществления обязательного государственного страхования жизни и здоровья военнослужащих. Правоотношение по реализации обязательного государственного страхования жизни и здоровья военнослужащих является сложным правоотношением и протекает, можно сказать, весь период военной службы (или прохождения военных

\footnotetext{
${ }^{16}$ URL: docme.ru>Учебник_правоведение (электронный ресурс). Дата обращения: 31.10.2012.

17 Под этапом в в энциклопедической литературе понимается отдельный момент, стадия какого-нибудь процесса Стадия же понимается как ступень, период, этап в развитии чего-л., имеющие свои качественные особенности. См.: Толковый словарь Ожегова. URL: dic.academic.ru>dic.nsf/dic_synonims/203855/. (электронный pecypc). Дата обращения: 31.10.2012. В данной статье автор полагает более предпочтительным использовать понятие «стадия» нежели «этап», так как именно качественные характеристики являются критериями разграничения стадий (этапов) реализации института обязательного государственного страхования жизни и здоровья военнослужащих.

18 Чеговадзе, Л. А. Структура и состояние гражданского правоотношения: дис. докт. юрид. наук. М., 2005. С. 47.
}

сборов - для граждан, пребывающих в запасе). Кроме того, в некоторых, установленных законодательством случаях, оно протекает и после окончания военной службы (военных сборов).

Анализ законодательства, в котором содержатся нормы права, регулирующие обязательное государственное страхование жизни и здоровья военнослужащих приводит к выводу о наличии нескольких стадий правоотношения по обязательному государственному страхованию жизни и здоровья военнослужащих. Критерием для выделения данных стадий является изменение состава участников и характера правовых связей между ними.

Первой стадией будет являться заключение Министерством Обороны Российской Федерации (иным федеральным органом, в котором законом предусмотрена военная служба) договора со страховщиком о страховании военнослужащего соответствующего федерального органа на основании проведенного конкурса среди страховых организаций. На этой стадии правоотношение по обязательному государственному страхованию жизни и здоровья военнослужащих будет носить гражданско-правовой характер, так как основано на равенстве сторон и имущественной самостоятельности его участников, несмотря на социальный характер цели заключаемого контракта - защита прав военнослужащего.

Следующей стадией правоотношения по обязательному государственному страхованию жизни и здоровья военнослужащих является поступление гражданина на военную службу (по призыву или по контракту, призыв гражданина для прохождения военных сборов) и приобретение им статуса застрахованного лица. Следует отметить, что статус застрахованного лица принимается военнослужащим независимо от его желания, хотя и в интересах военнослужащего, здесь он является мерой социальной защиты военнослужащего. На данной стадии правоотношение по обязательному государственному страхованию имеет преимущественно административно-правовой характер. Страхователем является Министерство Обороны Российской Федерации (иной федеральный орган исполнительной власти) в лице соответствующих командиров (начальников). В части отношений с Министерством Обороны Российской Федерации (иным федеральным органом исполнительной власти, в котором законом предусмотрено прохождение военной службы) военнослужащий находится в отношении власти-подчинения. Определяющим административно-правовой характер данных отношений является также и то, что правоотношение по обязатель- 
DOI: 10.7256/1811-9018.2014.2.7241

При цитировании этой статьи сноска на doi обязательна

\section{Право и политика 2 (170) 2014}

ному государственному страхованию непосредственно связано с прохождением военнослужащим военной службы. Со страховщиком военнослужащий не связан никакими административно-правовыми отношениями, несмотря на обусловленность договора страхования прохождением военной службы. Со страховщиком военнослужащий будет связан исключительно гражданско-правовыми отношениями. Мы полагаем, что особенность данной стадии заключается в том, что в случае, если в период прохождения военной службы (или в случаях, установленных законом - после ее окончания) не наступит никаких страховых случаев, то и не будет оснований для выплаты военнослужащему страхового возмещения. Данное правоотношение не будет реализовано, третьей стадии правоотношения в рассмотренном примере может и не возникнуть.

Особенность третьей стадии правоотношения по обязательному государственному страхованию жизни и здоровья военнослужащих заключается в том, что оно может возникнуть только лишь при фактическом наступлении страхового случая. Участниками (субъектами) данного правоотношения будут являться военнослужащий и командир воинской части (начальник органа военного управления). Юридическим фактом, явившимся основанием к возникновению данного правоотношения будет наступление указанного в законе страхового случая. На этой стадии командир воинской части (начальник органа военного управления) обязан провести расследование по факту получения травмы военнослужащим (принять иные меры, предусмотренные законом), признать произошедший случай либо страховым, либо не являющимся страховым, а также принять решение о направлении документов в страховую компанию для осуществления выплаты страхового возмещения или отказе в направлении документов. На этой стадии указанное правоотношение будет носить административно-правовой характер, так как оно возникает между субъектами, находящимися между собой в отношениях власти-подчинения, а также в связи с указанными отношениями. Предусмотрен специальный порядок оспаривания военнослужащим действий командира по направлению или отказу в направлении документов в страховую компанию. Оспаривание действий командира (начальника) на данной стадии производится в порядке оспаривания действий (решений) государственных органов или должностных лиц.

Четвертая стадия правоотношения по обязательному государственному страхованию жизни и здоровья военнослужащих возникает в случае направления к страховщику документов для выплаты страхового воз- мещения. Для того, чтобы направить страховщику документы по выплате страхового возмещения, командир воинской части, начальник органа военного управления должен признать факт получения травмы (гибели) военнослужащего страховым случаем, а также наличие оснований к получению военнослужащим страховой выплаты. На данной стадии участниками правоотношения по обязательному государственному страхованию выступают военнослужащий, как застрахованное лицо (либо иной выгодоприобретатель в случае гибели военнослужащего), с одной стороны и страховщик, на котором лежит обязанность по выплате страхового возмещения - с другой стороны. На данной стадии названное правоотношение носит гражданско-правовой характер, участниками правоотношения выступают равноправные субъекты, не находящиеся между собой в отношении власти-подчинения, имущественно самостоятельные. Обжалование действий страховщика на данной стадии отношения будет производиться в общем исковом порядке гражданского судопроизводства, а не в порядке оспаривания действий должностных лиц. C окончанием указанной стадии правоотношения по обязательному государственному страхованию жизни и здоровья военнослужащих оканчивается и реализация права военнослужащего на осуществление обязательного государственного страхования жизни и здоровья при наступлении страхового случая. Указанная стадия может окончиться либо принятием решения о производстве страховой выплаты военнослужащему или об отказе в осуществлении страховой выплаты.

Последующие стадии реализации института обязательного государственного страхования жизни и здоровья военнослужащих, по мнению автора, будут носить факультативный характер, так как связаны с непосредственным получением страховой выплаты либо обжалования действий страховой компании, отказавшей в выплате.

В контексте предложенного автором разделения процесса реализации института обязательного государственного страхования жизни и здоровья военнослужащих на определенные стадии, автор полагает необходимым отметить не только теоретическую, но и практическую значимость указанного разделения, которая заключается в выявлении проблем реализации института обязательного государственного страхования жизни и здоровья военнослужащих на отдельных стадиях.

Например, на третьей и четвертой стадии осуществления института обязательного государственного страхования жизни и здоровья военнослужащих может 
возникнуть проблема, связанная с направлением документов в компанию, осуществляющую выплату по обязательному государственному страхованию (3-я стадия), либо с осуществление выплат по обязательному государственному страхованию (4-я стадия).

Эта проблема заключается в следующем. П. 1 ст. 964 ГК РФ в качестве основания освобождения страховщика от выплаты страхового возмещения и страховой суммы указывает наступления страхового случая в результате военных действий. Указание на военные действия как основания освобождения от ответственности по выплате страхового возмещения подчеркивает важность определения данного понятия, которое особо актуальным становится в условиях военного положения.

Проблема заключается в определении самого понятия «военные действия», которое содержится в энциклопедической литературе ${ }^{19}$, но в самом же законодательстве понятие военных действий отсутствует.

Отсутствует это понятие и в Военной доктрине Российской Федерации ${ }^{20}$, в Стратегии национальной безопасности ${ }^{21}$. В статье 15 Военной доктрины Российской Федерации раскрывается предполагаемый характер военных действий, однако в ней не рассматривается само понятие военных действий.

Пп. 1 п. 1 ст. 4 Федерального закона «Об обороне» от 31 мая 1996 г. № 61-Ф3, говоря о прекращении военных действий, также не раскрывает самого понятия военных действий ${ }^{22}$.

Гражданский Кодекс Российской Федерации, помимо упомянутого выше случая использования понятия «военные действия», неоднократно упоминает данное понятие в других статьях ${ }^{23}$.

Автор полагает необходимым понятие «военных действий» закрепить в действующем законодательстве, где будет закреплено понятие военных действий.

Другая проблема, которая может возникнуть на 3-й и 4-й стадии реализации института обяза-

\footnotetext{
${ }^{19} \mathrm{~B}$ энциклопедической литературе под военными действиями понимается действия вооруженных сил во время войны, направленные на разгром противника на суше, в воздухе и на море: Красильников С. Н. Словарь основных военных терминов / под ред. С. Н. Красильникова. М., 1965. С. 47.

${ }^{20} \mathrm{O}$ военной доктрине Российской Федерации: указ Президента РФ от 5 февр. 2010 г. № 146 // Рос. газ. 2010. 8 февр.

${ }^{21}$ О Стратегии национальной безопасности Российской Федерации до 2020 года: указ Президента РФ от 12 мая 2009 г. N 537 [Электронный pecypc]. URL: www.kadet.ru/doc/SNBRF.htm. (дата обращения 21.02.2011)

${ }^{22}$ Собр. законодательства Рос. Федерации. 1996. № 23. Ст. 2750.

${ }^{23}$ Гражданский Кодекс Российской Федерации. П. 2 ст. 45, п. 2 ст. 794.
}

тельного государственного страхования жизни и здоровья военнослужащих, заключается в том, что в выше упомянутой ст. 964 п. 1 Гражданского Кодекса Российской Федерации в качестве основания освобождения страховщика от выплаты страхового возмещения указывается наступление страхового случая в результате «гражданской войны, народных волнений всякого рода или забастовок».

В законодательстве Российской Федерации отсутствует в настоящее время понятие «гражданской войны». В Военной доктрине рассмотрены все возможные виды войн, общим признаком для которых является противостояние между двумя государствами, что никак не подходит для гражданской войны, предусматривающей противоборство между двумя противостоящими друг другу силами одного государства. Общим для вооруженного конфликта и всех видов войн является понятие «военный конфликт», под которым понимается форма разрешения межгосударственных или внутригосударственных противоречий с применением военной силы, но и при его анализе не находится место понятию «гражданской войны». В ст. 6 Военной доктрины Российской Федерации дается понятие «вооруженного конфликта» как вооруженного столкновения ограниченного масштаба между государствами (международный вооруженный конфликт) или противостоящими сторонами в пределах территории одного государства (внутренний вооруженный конфликт). Представляется, что понятие внутреннего вооруженного конфликта, в большей степени, чем другие подходит к понятию «гражданская война».

Если исходить из замены понятия «гражданская война» на понятие «внутренний вооруженный конфликт», то неопределенным представляется вопрос о понятии противостоящих сторон в пределах территории одного государства. Возможно, под ними подразумеваются группы граждан Российской Федерации, иностранных граждан или лиц без гражданства, постоянно проживающих на территории Российской Федерации, преследующих противоположные политические цели или же в это понятие заложен совсем иной смысл. В этом контексте, по мнению автора, понятие «гражданская война» следует заменить на понятие «военный конфликт».

Таким образом, правоотношение по обязательному государственному страхованию жизни и здоровья военнослужащих является сложным правоотношением, которое можно разделить на несколько стадий. На каждой из рассмотренных стадий названное правоотношение может иметь либо административно- 
DOI: $10.7256 / 1811-9018.2014 .2 .7241$

При цитировании этой статьи сноска на doi обязательна

\section{Право и политика $2(170) \cdot 2014$}

правовой, либо гражданско-правовой характер, преимущественно в зависимости от участников данного правоотношения на каждой стадии.

Как показывает практика, отказ в выплате страхового возмещения чаще всего возникает на 4-й стадии реализации военнослужащим права на осуществление обязательного государственного страхования жизни и здоровья военнослужащих, так как именно финансовые интересы страховщика затрагиваются при выплате страхового возмещения.

Как видно, на каждой из стадий реализации правового института обязательного государственного страхования жизни и здоровья военнослужащих, преобладает либо административно-правовые, либо гражданско-правовые начала. Несомненно, в любой из рассмотренных стадий, институт обязательного государственного страхования жизни здоровья военнослужащих имеет социальную направленность. Однако, характер этой направленности весьма разнообразен, что не позволяет безапелляционно отнести этот правовой институт к раву социального обеспечения.

В 1-й и 4-й стадиях реализации правового института обязательного государственного страхования военнослужащих преобладают гражданскоправовые начала в регулировании общественных отношений, а во 2-й и 3-й стадии - административно-правовые начала.

Однако, нельзя забывать о том, что институт обязательного государственного страхования жизни и здоровья военнослужащих является целостным, комплексным правовым институтом, и его разделение на стадии правового регулирования по этой причине является весьма условным. Таким образом, неверным было бы отнести институт обязательного государственного страхования жизни и здоровья военнослужащих к сугубо гражданско-правовому институту, к институту права социального обеспечения, к институту административного права или к другим правовым институтам.

Исключение, тем не менее, составляет включение данного правового института как неотъемлемого элемента в систему военного права.

Анализ паспорта специальности «20.02.03 Военное право, военные проблемы международного права» с полной уверенностью позволяет говорить об этом. Одной из областей исследования названной специальности является правовой статус военнослужащих.

Н. В. Артамонов именует правовой статус военнослужащих правовым статусом особого рода, обусловливая данный вывод закреплением правового статуса военнослужащих в нормах различных отраслей права ${ }^{24}$. Особенности этого правового института, в свою очередь, обусловливаются особенностями прохождения военной службы. Военнослужащие пользуются гражданскими правами и свободами с ограничениями, определяемыми условиями военной службы, и в соответствии с условиями военной службы им предоставляются дополнительные права, гарантии и компенсации ${ }^{25}$. По мнению А. В. Кудашкина, главная особенность военной службы состоит в исполнении военнослужащими специфических функций, связанных с применением или возможностью применения средств вооруженной борьбы, в целях решения государственными органами и организациями задач в области защиты Отечества (обороны и военной безопасности), закрепленных за ними в нормативном порядке ${ }^{26}$. Названная особенность военной службы с различными модуляциями подчеркивается как правовыми актами Конституционного Суда Российской Федерации ${ }^{27}$, так и трудами ученых в сфере военного права ${ }^{28}$.

Особенности правового статуса военнослужащих, в свою очередь, обуславливают особенности правового института обязательного государственного страхования жизни и здоровья военнослужащих. Право на обязательное государственное страхование жизни и здоровья присуще исключительно военнослужащим и связано с особенностями их правового статуса и особенностями прохождения военной службы.

Кроме того, особенности, правового института обязательного государственного страхования жизни и здоровья военнослужащих определяется сложностью и многогранностью правового статуса указанной категории граждан, который состоит из следующих

\footnotetext{
${ }^{24}$ Артамонов Н. В. Правовой статус военнослужащих в СССР // Советское государство и право. 1983. № 5. С. 26.

${ }^{25}$ Мигачев Ю. И. Правовые гарантии реализации статуса военнослужащих (сравнительно-правовое исследование): автореф. дис. ... докт. юрид. наук. М. 1998. С. 22; Артамонов Н. В. Правовой статус советских военнослужащих и его обеспечение: учеб. пособие. С. 11; Кудашкин А. В. Теоретико-правовые основы военной службы в Российской Федерации. С. 82.

${ }^{26}$ Кудашкин А. В. Военная служба в Российской Федерации теория и практика правового регулирования. М., 2003.

27 Постановление Конституционного Суда Российской Федерации от 20 окт. 2010 г. № 18-П // Собр. законодательства Рос. Федерации. 2010. № 43. Ст. 5578; Определение Конституционного суда РФ № 17-П от 26 декабря 2002 г. // Вестник Конституционного Суда РФ. 2003. № 1 .

${ }^{28}$ Корякин В. М. Введение в теорию военного права: монография // Российский военно-правовой сборник. № 9. М.: За права военнослужащих, 2007. С. 51
} 
составных частей: общей, относящейся к правовому статусу любого гражданина ${ }^{29}$; специальной (совокупность военно-служебных прав и обязанностей); особенной (комплекс черт, характеризующих правовое положение военнослужащих); единичной, включающей в себя правовое положение каждого конкретного военнослужащего ${ }^{30}$. Право на осуществление обязательного государственного страхования военнослужащих, как было отмечено в начале статьи, является неотъемлемой частью правового статуса военнослужащих. Это право входит в общегражданскую часть правового статуса военнослужащих, специально для них предусмотренную.

Таким образом, институт обязательного государственного страхования жизни и здоровья военнослужащих является неотъемлемым элементом системы военного права. Ввиду комплексного характера указанного правового института, включение его как элемента какой-либо иной отрасли права представляется необоснованным.

Учитывая изложенное, проанализировав приведенные мнения ученых - юристов можно отметить, что основной недостаток указанных вывод ученых - это одностороннее рассмотрение института обязательного государственного страхования жизни и здоровья военнослужащих, без учета всей сложности и многогранности данного правового отношения, разнообразия участников правоотношения на различных его стадиях и характера связи между ними. При рассмотрении института обязательного государственного страхования жизни и здоровья военнослужащих необходимо учитывать преобладание гражданско-правового или административно-правового начала в правоотношениях между его участниками.

Представленное в качестве новации государственного строительства стран-членов мирового сообщества конституционное положение Основного Закона Российской Федерации по линии провозглашения социальной политики России как направленной « на создание условий, обеспечивающих достойную жизнь и свободное развитие человека» выводит Российское государства в разряд передового, социального ориен-

\footnotetext{
${ }^{29}$ При этом общую часть этого статуса он разделял на общегражданскую, равно относящуюся и к военнослужащим и ко всем остальным категориям граждан и общегражданскую часть, предусмотренную специально для военнослужащих. См.: Артамонов Н. В. Правовой статус военнослужащих в СССР и его обеспечение. М., 1984. С. 15.

${ }^{30}$ Артамонов Н. В. Правовой статус военнослужащих в СССР // Советское государство и право. 1983. № 5. С. 26; Мигачев Ю. И. Правовые гарантии реализации статуса военнослужащих: монография. С. 11-12.
}

тированного гражданского общества, где права и свободы человека обеспечиваются в должных параметрах органов правосудия.

Последовательное осуществление предписаний института обязательного государственного страхования жизни и здоровья военнослужащих, как он проявляет себя в параметрах конституционно-правового поля Российского государства, всецело подтверждает факт заявленной приверженности верховенству права внутри страны и вовне. Позитив права, обозначенный в положениях Конституции Российской Федерации, а также в соответствующих международно-правовых актах (Международный пакт об экономических, социальных и культурных правах 1966 г.), по обстоятельства заявленной приверженности России верховенству права создаёт собой должную юридическую основу для всестороннего претворения в жизнь такого важного института, как институт обязательного государственного страхования жизни и здоровья военнослужащих.

\section{Библиография:}

1. Конституция Российской Федерации (принята всенародным голосованием 12 декабря 1993 г.) // Собрание Законодательства РФ. 2009. № 4. Ст. 445.

2. Гражданский кодекс Российской Федерации (части первая, вторая, третья): федер. закон, 30 нояб. 1994. № 51-Ф3 // Собрание Законодательст-ва РФ, 05.12. 1994, . № 32, . Ст. 3301, 1996. № 5. Ст. 410.

3. О статусе военнослужащих: федер. закон, 27 мая 1998. № 76-ФЗ // Собрание Законодательства РФ. 1998. № 22. Ст.2331.

4. Об обязательном государственном страховании жизни и здоровья военнослужащих, граждан, призванных на военные сборы, лиц рядового и начальствующего состава органов внутренних дел Российской Федерации, Государственной противопожарной службы, органов по контролю за оборотом наркотических средств и психотропных веществ, сотрудников учреждений и органов уголовно-исполнительной системы и сотрудников федеральных органов налоговой полиции: федер. закон, 28 марта 1998 г. № 52-Ф3 Собр. законодательства Российской Федерации, 2001. № 49. Ст. 4552. О военной доктрине Российской Федерации: указ Президента РФ от 5 февр. 2010 г. № 146 // Рос. газ. 2010. 8 февр.

5. О Стратегии национальной безопасности Российской Федерации до 2020 года: указ Президента РФ 


\section{Право и политика $2(170) \cdot 2014$}

от 12 мая 2009 г. N 537 [Электронный ресурс]. URL: www.kadet.ru/doc/SNBRF.htm. (дата обращения 21.02.2011).

6. Постановление Конституционного Суда РФ, 20 окт. 2010. № 18-П // Собрание законодательства Российской Федерации. 2010. № 43. Ст. 5578.

7. Определение Конституционного суда РФ, 26 дек. 2002. № 17-П // Вестник Конституционного Суда РФ. № 1. 2003.

8. Черниченко С.В. Теория международного права. T. 1. M., 1995;

9. Зимненко Б.Л. Международное право и правовая система Россий-ской Федерации. М., 2006;

10. Гавердовский А.С. Имплементация норм международного права. Киев, 1980;

11. Каламкарян Р.А. Имплементация норм международного права в правовой системе РФ. / Гражданин и права. 2011.№10 .c.3-13.

12. Конституционное право России: учебник для студентов вузов / А.С. Прудников и др.; под ред. Б.С. Эбзеев, А.С. Прудников, В.И. Авсеенко. М., 2010

13. Ковалевский М.А. Конституционные принципы в обязательном страховании военнослужащих и проблема ответственности страховщика. // Страховое право. 2002. № 4.

14. Мачкасов А.И. Осуществление обязательного государственного страхования жизни и здоровья сотрудников Уголовно-исполнительной систе-мы. Дисс... канд. юрид. наук. Рязань, 2010.

15. Савкин Д.В. Страховое правоотношение по российскому граждан-скому праву. Дис... канд. юрид. наук. М., 2003. С. 6.

16. Чеговадзе, Л. А. Структура и состояние гражданского правоотношения: дис. докт. юрид. наук. М., 2005.

17. Красильников С. Н. Словарь основных военных терминов / под ред. С. Н. Красильникова. М., 1965.

18. Артамонов Н. В. Правовой статус военнослужащих в СССР // Советское государство и право. 1983. № 5.

19. Мигачев Ю. И. Правовые гарантии реализации статуса военнослужащих (сравнительно-правовое исследование): автореф. дис. ... докт. юрид. наук. M. 1998;

20. Артамонов Н. В. Правовой статус советских военнослужащих и его обеспечение: учеб. пособие.

21. Кудашкин А. В. Военная служба в Российской Федерации теория и практика правового регулирования. М., 2003.
22. Корякин В. М. Введение в теорию военного права: монография // Российский военно-правовой сборник. № 9. М.: За права военнослужащих, 2007.

23. Артамонов Н. В. Правовой статус военнослужащих в СССР // Советское государство и право. 1983. № 5.

\section{References (transliteration):}

1. Chernichenko S.V. Teoriya mezhdunarodnogo prava. T. 1. M., 1995;

2. Zimnenko B.L. Mezhdunarodnoe pravo i pravovaya sistema Rossii-skoi Federatsii. M., 2006;

3. Gaverdovskii A.S. Implementatsiya norm mezhdunarodnogo prava. Kiev, 1980;

4. Kalamkaryan R.A. Implementatsiya norm mezhdunarodnogo prava v pravovoi sisteme RF. / Grazhdanin i prava. 2011.№10 .s.3-13.

5. Kovalevskii M.A. Konstitutsionnye printsipy v obyazatel'nom strakhovanii voennosluzhashchikh i problema otvetstvennosti strakhovshchika. // Strakhovoe pravo. 2002. № 4.

6. Machkasov A.I. Osushchestvlenie obyazatel'nogo gosudarstvennogo strakhovaniya zhizni i zdorov'ya sotrudnikov Ugolovno-ispolnitel'noi siste-my. Diss... kand. yurid. nauk. Ryazan', 2010.

7. Savkin D.V. Strakhovoe pravootnoshenie po rossiiskomu grazhdan-skomu pravu. Dis... kand. yurid. nauk. M., 2003. S. 6.

8. Chegovadze, L. A. Struktura i sostoyanie grazhdanskogo pravootnosheniya: dis. dokt. yurid. nauk. M., 2005.

9. Krasil'nikov S. N. Slovar' osnovnykh voennykh terminov / pod red. S. N. Krasil'nikova. M., 1965.

10. Artamonov N. V. Pravovoi status voennosluzhashchikh v SSSR // Sovetskoe gosudarstvo i pravo. 1983. № 5.

11. Migachev Yu. I. Pravovye garantii realizatsii statusa voennosluzhashchikh (sravnitel'no-pravovoe issledovanie): avtoref. dis. ... dokt. yurid. nauk. M. 1998;

12. Artamonov N. V. Pravovoi status sovetskikh voennosluzhashchikh i ego obespechenie: ucheb. posobie. .

13. Kudashkin A. V. Voennaya sluzhba v Rossiiskoi Federatsii teoriya i praktika pravovogo regulirovaniya. M., 2003.

14. Koryakin V. M. Vvedenie $\mathrm{v}$ teoriyu voennogo prava: monografiya // Rossiiskii voenno-pravovoi sbornik. № 9. M.: Za prava voennosluzhashchikh, 2007.

15. Artamonov N. V. Pravovoi status voennosluzhashchikh v SSSR // Sovetskoe gosudarstvo i pravo. 1983. № 5. 